\title{
Evaluation of impact of educational intervention on knowledge and practice regarding breast self-examination among paramedical workers in a teaching hospital Maharashtra, India
}

\author{
Shubhada Sunil Avachat*, Vijaya Jayant Thipse, Sandip Arunrao Joshi
}

Dr. Vikhe Patil Medical College, Ahmednagar, Maharashtra, India

Received: 14 June 2016

Accepted: 02 July 2016

\section{*Correspondence:}

Dr. Shubhada Sunil Avachat,

E-mail: shubhadasunil@gmail.com

Copyright: ( ) the author(s), publisher and licensee Medip Academy. This is an open-access article distributed under the terms of the Creative Commons Attribution Non-Commercial License, which permits unrestricted non-commercial use, distribution, and reproduction in any medium, provided the original work is properly cited.

\begin{abstract}
Background: Breast self-examination (BSE) is an appropriate strategy for early case detection and improve survival of breast cancer and is probably the most feasible approach to wide population coverage in many developing countries. Health workers play a key role in disseminating the knowledge in community however several studies conducted in different countries documented poor knowledge among them. Hence present study was conducted to evaluate the change in knowledge level after educational intervention about BSE among paramedical workers.

Methods: An interventional study was conducted among 80 paramedical workers (nurses, lab technicians and social workers) of a teaching hospital and changes in knowledge were assessed with the help of pre designed questionnaire. Data was analyzed using appropriate statistical techniques.

Results: The mean score of knowledge changed from 8.55 to 12.48 after the training. Majority of the paramedical workers $(73 \%)$ had poor or average knowledge about BSE and significant improvement occurred in the knowledge level after the intervention.

Conclusions: The knowledge regarding BSE was poor or average among the paramedical workers and educational intervention positively changed the knowledge level among them and almost all paramedical workers desired to impart this knowledge to the community.
\end{abstract}

Keywords: Paramedical workers, BSE, Educational intervention

\section{INTRODUCTION}

Breast cancer is by far the most frequent cancer among women in both developed countries and developing countries (25\% of all cancers). In India, breast cancer incidence rate reported was 25.8 per lac population during 2012 and mortality rate was 12.7 per lac ranking number one killer in women. ${ }^{1}$ The American Cancer Society guidelines for early detection of breast cancer recommend yearly mammogram starting at the age of forty, clinical breast examination once in every three years for women in their twenties and thirties, and every year for women at age forty and over. ACS also recommends Breast self-examination (BSE) for women starting in their twenties. ${ }^{2-4}$
Breast self-examination is one of the basic technique for early detection of breast cancer. ${ }^{5}$ Early detection and treatment yields favorable outcome in terms of survival. The purpose of breast self-examination is to increase the self-awareness and to help the woman to detect any abnormality in appearance or feel of breast.

Breast self-examination is an useful adjuvant to early case detection in many countries and probably the most acceptable and feasible approach for wide population coverage. ${ }^{6}$

Several studies have documented that health worker's knowledge and attitude is the most important factors which influence the screening programs for breast 
cancer. $^{7-8}$ However, poor awareness and knowledge about breast cancer symptoms and screening methods has been previously reported for their poor out come by several different studies. ${ }^{9-10}$ For promotion of public health measure like breast self-examination among community, health care providers should be well equipped with comprehensive knowledge. Hence the present study was conducted among health workers in a teaching hospital to assess their baseline knowledge, to identify gaps in knowledge and to assess changes in knowledge after an educational intervention.

\section{METHODS}

\section{Study design}

Interventional study, Health education (HE) was used as an intervention

\section{Study setting}

Medical college hospital in urban area

\section{Study participants}

Paramedical female workers in a hospital.

Sampling technique and sample size-All paramedical workers from the hospital like nurses; lab technicians and medical social workers who were ready to participate were included in the study

\section{Inclusion criteria}

All paramedical female workers above 20 years of age and ready to participate comprising of 53 nurses, 24 lab technicians and three medical social workers participated in the study and the sample size was 80 .

\section{Study duration}

Oct. 2015 to Mar 2016 (six months).

\section{Data collection}

Data was collected with the help of pre designed questionnaire prepared by search of previous literature on subject. $^{9-12}$ Both open and closed ended questions were used to assess knowledge, attitude and practice of breast self examination. General information like age, education, occupation, marital status, number of children was recorded.

Baseline knowledge was assessed prior to intervention with the help of questionnaire. Educational intervention was imparted to the participants by lectures, demonstration and video clips. The same questionnaire was used to assess the change in knowledge after the intervention. The answers were evaluated and each correct answer was given one mark, Total 20 questions were asked and the impact of intervention was assessed by comparing the score prior and after educational interventions as stated earlier. Grading of knowledge was done as follows, <35 \% score as poor, >35--55\% as average, $>55-75 \%$ as good and $>75 \%$ as excellent.

\section{Statistical analysis (SA)}

The pre intervention and post intervention data was compiled and analyzed using statistical techniques like percentages, proportions and appropriate tests of significance like chi square test and standard error of difference between means were applied.

\section{RESULTS}

An interventional study was conducted among 80 paramedical workers to evaluate the impact of education regarding breast self-examination (BSE). Majority of the participants $(67.5 \%)$ were in the age group of $20-40$ years, $65 \%$ were married. 37\% participants had one child, $24 \%$ of them had two and four \% had more than two children , while $30 \%$ participants were nulliparous.

The mean score of knowledge prior to intervention was 8.55, which changed to 12.48 after the intervention. After applying the test of significance (standard error of difference between two means) significant improvement of knowledge was observed $(\mathrm{p}<0.005)$.

Majority of the paramedical workers $(73 \%)$ had poor or average knowledge prior to intervention and significant improvement occurred in the knowledge level after the intervention (Table 1).

Table 1: Change in knowledge level of the participants (pre and post-test).

\begin{tabular}{|ll|l|l|}
\hline Knowledge level & $\begin{array}{l}\text { No. of participants } \\
\text { Prior to intervention }\end{array}$ & $\begin{array}{l}\text { No. of participants after } \\
\text { intervention }\end{array}$ & Total \\
\hline Poor $(<35 \%)$ & $30(37.5 \%)$ & $03(3.7 \%)$ & 33 \\
\hline Average $(>35-55 \%)$ & $29(36.2 \%)$ & $18(22.5 \%)$ & 47 \\
\hline Good $(>55-75 \%)$ & $17(21.2 \%)$ & $40(50 \%)$ & 57 \\
\hline Excellent $(>75 \%)$ & $04(5 \%)$ & $19(23.7 \%)$ & 23 \\
\hline Total & 80 & 80 & 160 \\
\hline
\end{tabular}


Table 2: Changes in knowledge regarding BSE $(n=80)$.

\begin{tabular}{|llll|}
\hline Variables & $\begin{array}{l}\text { Correct response } \\
\text { prior intervention }\end{array}$ & $\begin{array}{l}\text { Correct response } \\
\text { after intervention }\end{array}$ & Significance level \\
\hline $\begin{array}{l}\text { Age after which BSE } \\
\text { should be started }\end{array}$ & $41(51.2 \%)$ & $61(76.2 \%)$ & $\mathrm{Z}=3.26, \mathrm{p}<0.005$ Significant \\
\hline $\begin{array}{l}\text { How frequently BSE } \\
\text { should be done }\end{array}$ & $31(38.7 \%)$ & $66(82.5 \%)$ & $\begin{array}{l}\mathrm{X}^{2}=31.6, \mathrm{p}<0.001 \text { highly } \\
\text { significant }\end{array}$ \\
\hline $\begin{array}{l}\text { When to perform BSE } \\
\text { before menopause }\end{array}$ & $17(21.2 \%)$ & $50(62.5 \%)$ & $\mathrm{Z}=5.9, \mathrm{p}<0.005$ Significant \\
\hline $\begin{array}{l}\text { When to perform BSE } \\
\text { after menopause }\end{array}$ & $23(28.7 \%)$ & $52(65) \%$ & $\mathrm{Z}=4.9, \mathrm{p}<0.005$, Significant \\
\hline
\end{tabular}

Out of 80 participants, $56(70 \%)$ had the opinion that BSE is necessary $20 \%$ felt that doing BSE will give awkward feeling while after the training $95 \%$ women agreed that BSE is necessary.

Only $19(23.7 \%)$ paramedical workers had ever done breast self-examination and only $5(6.2 \%)$ were doing BSE regularly.

Out of 80 participants $41(50.1 \%)$ were knowing the correct technique of BSE and only $30 \%$ were knowing that BSE can be done at home in front of mirror and the percentage increased upto70\% after training. Only one fourth of the participants were aware about the day on which BSE should be done before menopause and after menopause after training three fourth of the participants had correct knowledge about it. Significant improvement occurred in practice related knowledge after intervention (Table 3, $\mathrm{P}<0.005$ ).

After the intervention almost all of the participants agreed that BSE is essential, beneficial and as a health worker they can impart necessary education regarding BSE to all the females coming to the hospital and in community.

Table 3: Impact on attitude and practice related response.

\begin{tabular}{|llll|}
\hline Variable & $\begin{array}{l}\text { Correct response } \\
\text { Prior intervention }\end{array}$ & $\begin{array}{l}\text { Correct response } \\
\text { After intervention }\end{array}$ & Significance level \\
\hline $\begin{array}{l}\text { Can early diagnosis of } \\
\text { breast cancer improve } \\
\text { survival? }\end{array}$ & $32(40 \%)$ & $68(85 \%)$ & $\mathrm{X}^{2}=5.4, \mathrm{p}<0.005$ Significant \\
\hline Is BSE beneficial? & $62(77.5 \%)$ & $76(95 \%)$ & $\mathrm{Z}=3.20, \mathrm{p}<0.005$ significant \\
\hline $\begin{array}{l}\text { Is this training essential for } \\
\text { every woman? }\end{array}$ & $66(82.5 \%)$ & $77(96.2 \%)$ & $\mathrm{Z}=2.7 \mathrm{p}<0.005$ significant \\
\hline How to perform BSE & $41(51.2 \%)$ & $57(71.2 \%)$ & $\mathrm{X}^{2}=6.72, \mathrm{p}<0.005$ significant \\
\hline $\begin{array}{l}\text { When BSE should be } \\
\text { performed? }\end{array}$ & $24(30 \%)$ & $56(70 \%)$ & $\begin{array}{l}\mathrm{X}^{2}=25.6, \mathrm{p}<0.001 \\
\text { highly significant }\end{array}$ \\
\hline
\end{tabular}

\section{DISCUSSION}

BSE is an appropriate screening test for breast cancer and practicing BSE can reduce the mortality by early detection of breast cancer. Health care providers can play an important role in disseminating this knowledge to the community.

Changes in knowledge regarding breast self examination were evaluated after educational intervention of paramedical workers of the medical college hospital. Significant improvement occurred in knowledge score, only $26.2 \%$ participants had good knowledge prior to training, this percentage increased up to $73 \%$ after the training. Similar finding was observed by Shalini et al in their study, knowledge scores shows that $72.5 \%$ of students had average knowledge on BSE in pre test and $85 \%$ of students had good knowledge score in post-test. ${ }^{12}$ Mojahed et al in his study conducted among nurses and midwives reported that only $13.21 \%$ had a good level of knowledge, most of them had a moderate and low level of knowledge of BSE. ${ }^{13}$

Prior to intervention, only $38.7 \%$ participants knew that BSE should be done every monthly, and only $21-28 \%$ were knowing that when BSE should be done ; after intervention significant improvement occurred ,82.7\% 
participants had given correct answer regarding frequency and $65 \%$ were aware about correct time of BSE. In study conducted by Dalal et al, Majority (89.2\%) of the participants knew that BSE is recommended to be done monthly and less than half of the study sample $(46.8 \%)$ was aware about the correct time of BSE. ${ }^{14}$

In present study $72 \%$ participants before training and 95\% participants after training agreed that BSE is beneficial and $85 \%$ participants after training agreed that early detection by BSE will improve survival chances. In study conducted by Raini et al , majority of respondents (72.5\%)had positive attitude towards BSE and 94.2\% agreed that early detection improves survival. ${ }^{15}$ Doshi et al also reported that almost all participants in their study agreed that all the women should do BSE.

Only $23 \%$ of paramedical workers had ever done breast self examination and only $6 \%$ were doing it regularly. Similar to our study, Dalal et al reported that only $17 \%$ of female medical students perform BSE regularly, Doshi et al also reported alarmingly low practice of performing BSE among dental students in his study in India. ${ }^{16}$ Other studies conducted in other countries among the health-care providers, also reported that practice of BSE was in the range of $28-70 \% .^{17-18}$

\section{CONCLUSION}

Breast self-examination is one of the strategies to reduce the mortality and improve the survival and health care providers need to be trained for effective implementation of this strategy. Educational intervention of paramedical workers significantly changed and improved the knowledge and awareness regarding BSE and almost all paramedical workers desired to impart this knowledge to the community.

\section{ACKNOWLEDGEMENTS}

Authors are grateful to the concerned authorities of Dr. Vikhe Patil Medical College for permitting the study and also to all paramedical workers of the hospital who participated in the study.

\section{Funding: No funding sources \\ Conflict of interest: None declared \\ Ethical approval: Not required}

\section{REFERENCES}

1. K Park, Park's Textbook of Preventive and Social Medicine. Jabalpur: Bhanot Publishers; 23rd edition. 2015:387-9.

2. Kerlikowske K, Hubbard RA, Miglioretti DL. Comparative effectiveness of digital versus filmscreen mammography in community practice in the Unit- ed States: A cohort study. Ann Intern Med. 2011;155:493-502.
3. Smith RA, Saslow D, Sawyer KA. American Cancer Society Guidelines for breast cancer screening: Update 2003. CA: A Cancer Journal for Clini- cians. 2003;53:141-69.

4. Semiglazov VF, Moiseenko VM, Manikhas AG. Intrim results of a prospective randomized study of self-examination for early detection of breast cancer. Voprosy Onkologii. 1999;45:265-71.

5. WHO Screening for breast cancer. Available from: http://www.who.int/cancer/detection/breastcancer/e $\mathrm{n} / .2008$.

6. Park K. Textbook of Preventive and Social Medicine, $23^{\text {rd }}$ edition: Bhanot Publishers; Jabalpur. 2015:386-9.

7. Lurie N, Margolis KL, McGovern PG, Mink PJ, Slater JS. Why do patients of female physicians have higher rates of breast and cervical cancer screening. J Gen Intern Med. 1997;12(1):34-43.

8. Bekker $\mathrm{H}$, Morrison L, Marteau TM. Breast screening: GPs' beliefs, attitudes and practices. Fam Pract.1999;16(1):60-5.

9. Okobia MN, Bunker CH, Okonofua FE, Osime U. Knowledge, attitude and practice of Nigerian women towards breast cancer: a cross-sectional study. World J Surg Oncol. 2006;4:11.

10. Mohamed HA, El-Naggar NS, Sayed HY. Knowledge, attitudes and practices regarding breast self-examination among female undergraduate students in the faculty of applied medical sciences at Umm Al-Qura University. Journal of American science. 2013;9:622-32.

11. Mahnoush R ,Seyed H, Gholamreza S. Knowledge, attitudes, and practice of breast self-examination among female health workers in Isfahan, Iran J Educ Health Promot. 2013; 2:46.

12. Divya S, Nayak VM. Awareness and Impact of Education on Breast Self-Examination Among College Going Girls Indian J Palliat Care. 2011; 17(2):150-4.

13. Mojahed SH, Dehghani FR, Dafei M. Knowledge and practice of the nursing staff hospital about breast self examination. J Shaeed Sdoughi Univ Med Sci Yazd. 2001;9:82-8.

14. Dalal MN, Sahar H, Al-Hanouf A, Al-Malki, Abrar A, Eiman M. Al-Otaibi. Knowledge, attitude and practice of breast self examination and breast cancer among female medical students in Taif, Saudi Arabia Open Journal of Preventive Medicine. 2014;4(2):69-77.

15. Iran M, Seyed H, Gholamreza S. Knowledge, attitudes, and practice of breast self-examination among female health workers in Isfahan. J Educ Health Promot. 2013;2:46.

16. Doshi D, Reddy S, Kulkarni S, Karunakar P. Breast self-examination: knowledge, attitude, and practice among female dental students in Hyderabad City, India Indian J Palliat Care. 2012;18(1):68-73.

17. Cavdar Y, Akyolcu N, Ozbaş A, Oztekin D, Ayoğu T, Akyüz N. Determining female physicians' and nurses' practices and attitudes toward breast self- 
examination in Istanbul, Turkey. Oncol Nurs Forum. 2007;34:1218-21.

18. Haji-Mahmoodi M, Montazeri A, Jarvandi S, Ebrahimi M, Haghighat S, Harirchi I. Breast selfexamination: Knowledge, attitudes, and practices among female health care workers in Tehran, Iran. Breast J. 2002;8:222-5.
Cite this article as: Avachat SS, Thipse VJ, Joshi SA. Evaluation of impact of educational intervention on knowledge and practice regarding breast selfexamination among paramedical workers in a teaching hospital Maharashtra, India. Int J Community Med Public Health 2016;3:2217-21. 